\title{
Article \\ Corrosion Behavior of AA2055 Aluminum-Lithium Alloys Anodized in the Presence of Sulfuric Acid Solution
}

\author{
Pedro Oliver Samaniego-Gámez ${ }^{1}$, Facundo Almeraya-Calderon ${ }^{1, * \mathbb{D}}$, Erick Maldonado-Bandala ${ }^{2}$, \\ Jose Cabral-Miramontes ${ }^{1}$ (D), Demetrio Nieves-Mendoza ${ }^{2}$, Javier Olguin-Coca ${ }^{3}$, Luis Daimir Lopez-Leon ${ }^{4}{ }^{(D)}$, \\ Luis G. Silva Vidaurri ${ }^{4}$, Patricia Zambrano-Robledo ${ }^{1}$ (D) and Citlalli Gaona-Tiburcio ${ }^{1, *(D)}$
}

1 Universidad Autónoma de Nuevo León, FIME-Centro de Investigación e Innovación en Ingeniería Aeronáutica (CIIIA), Av. Universidad s/n, Ciudad Universitaria, San Nicolás de los Garza N.L. 66455, Mexico; pedro.samaniegogm@uanl.edu.mx (P.O.S.-G.); jose.cabralmr@uanl.edu.mx (J.C.-M.); patricia.zambranor@uanl.edu.mx (P.Z.-R.)

2 Universidad Veracruzana, Facultad de Ingeniería Civil, Xalapa 91000, Mexico; erimaldonado@uv.mx (E.M.-B.); dnieves@uv.mx (D.N.-M.)

3 Universidad Autónoma del Estado de Hidalgo, Área Académica de Ingeniería y Arquitectura, Carretera Pachuca-Tulancingo Km. 4.5, Pachuca de Soto 42082, Mexico; olguinc@uaeh.edu.mx

4 Centro de Investigación en Materiales Avanzados Subsede Monterrey (CIMAV), Alianza Norte 202, PIIT, Autopista Monterrey-Aeropuerto, Km. 10, Apodaca 66628, Mexico; luis_lopez@uaeh.edu.mx (L.D.L.-L.); luis.silva@cimav.edu.mx (L.G.S.V.)

check for updates

Citation: Samaniego-Gámez, P.O.; Almeraya-Calderon, F.; MaldonadoBandala, E.; Cabral-Miramontes, J.; Nieves-Mendoza, D.; Olguin-Coca, J.; Lopez-Leon, L.D.; Silva Vidaurri, L.G.; Zambrano-Robledo, P.; GaonaTiburcio, C. Corrosion Behavior of AA2055 Aluminum-Lithium Alloys Anodized in the Presence of Sulfuric Acid Solution. Coatings 2021, 11, 1278 https://doi.org/10.3390/coatings 11111278

Academic Editor: Alina Pruna

Received: 15 September 2021

Accepted: 18 October 2021

Published: 21 October 2021

Publisher's Note: MDPI stays neutra with regard to jurisdictional claims in published maps and institutional affiliations.

Copyright: (c) 2021 by the authors. Licensee MDPI, Basel, Switzerland. This article is an open access article distributed under the terms and conditions of the Creative Commons Attribution (CC BY) license (https:// creativecommons.org/licenses/by/ $4.0 /)$.
* Correspondence: facundo.almerayacld@uanl.edu.mx (F.A.-C.); citlalli.gaonatbr@uanl.edu.mx (C.G.-T.)

Abstract: The aim of this work was to evaluate the corrosion behavior of the AA2055 Aluminumlithium alloy anodized in a sulfuric acid $\left(\mathrm{H}_{2} \mathrm{SO}_{4}\right)$ bath, varying the current density of 0.19 and $1 \mathrm{~A} \cdot \mathrm{cm}^{-2}$ and why the sealing solution was water $\left(\mathrm{H}_{2} \mathrm{O}\right)$ and sodium dichromate $\left(\mathrm{Na}_{2} \mathrm{Cr}_{2} \mathrm{O}_{7}\right)$. Anodized samples were exposed to a 10 vol. $\% \mathrm{H}_{2} \mathrm{SO}_{4}$ solution and the electrochemical technique used was electrochemical impedance spectroscopy. Scanning electron microscopy and X-ray photoelectron spectroscopy were employed to characterization of the anodizing layer, determinate morphology and thickness of coatings. The $\mathrm{Na}_{2} \mathrm{Cr}_{2} \mathrm{O}_{7}$ sealing solution tends to increase the charge transfer resistance and produces a more homogeneous and compact passive oxide layer, and imparts a corrosion inhibition protection to the AA2055. SEM observations indicated that the morphology and thickness of the anodic films formed on AA2055 aluminum-lithium alloy anodized have the best results for both current densities.

Keywords: anodizing; aluminum-lithium 2055 alloy; corrosion; SEM; XPS; electrochemical impedance spectroscopy

\section{Introduction}

Anodizing is an electrochemical process used to increase the thickness of the oxide layer on the surface of aluminum and its alloys. Anodizing treatment is a method of conversion coatings in an electrolytic cell for surface protection on aluminum and its alloys in aerospace and aeronautical applications [1-6].

The development of the aluminum-lithium alloys (known as the third generation) has been used by the aeronautical and other applications due to its good properties, replacing conventional $\mathrm{Al}-\mathrm{Cu}$ and $\mathrm{Al}-\mathrm{Zn}$ alloys, resulting in an increase in payload and fuel efficiency [7,8]. Al-Li alloys have a characteristic that a reduction in density is to their advantage, and lithium, being the lightest metal, would have the greatest influence on reducing the density of aluminum. Another advantage of this alloy is that it has a lower flat mechanical anisotropy, good resistance to SCC and fracture toughness [9-16]. Therefore, low density, high strength and rigidity are one of the main alloys in aircraft manufacturing; for example, reinforcing the fuselage, floor beams and wing stringers 
of aircrafts [17]. Over the last decade, it has been reported [16,18-21] that several thirdgeneration alloys have been qualified for use in aircraft such as the Airbus 380; among these alloys is AA2055 (developed by Alcoa), which combines density, mechanical resistance and corrosion properties; density $\left(2.71 \mathrm{~g} / \mathrm{cm}^{3}\right)$ is 4 to $5 \%$ less than high-strength $7 x x x$ alloys, mechanical strength is similar to a AA7051 and superior to AA7075 and AA7050 alloys. Corrosion resistance (pitting and SCC) in accelerated environments of the AA2055 alloy is similar to or better than AA7xxx alloys with different heat treatments.

The interaction of aluminum in contact with different atmospheres results in the formation of a protective oxide layer on the surface of aluminum alloys. Localized corrosion and the formation of galvanic microcells in the microstructure can be present in aluminum alloys exposure in corrosive substances, making them susceptible to electrochemical degradation $[6,19,22]$. With electrochemical treatment of anodizing, it is possible to increase the resistance to corrosion, and improve its mechanical properties by generating a thicker artificial oxide film [19]. Ma et al. mentioned that the aerospace aluminum alloys need surface finishing by anodizing to provide the required corrosion resistance under service conditions [7].

The aluminum anodizing process is generally done with sulfuric acid, which generates a dense oxide layer and has high porosity, good adsorption, thick film layers, and good wear resistance that provides protection against corrosion [5,23]. It can also be combined with organic acids, to achieve improvements on surface adhesion, thickness, and corrosion inhibition, among others [3,5,8,23-25]. In anodizing treatment, the $\mathrm{Al}_{2} \mathrm{O}_{3}$ layer is formed that is fine, compact, porous, and an external barrier. Being a porous oxide layer, such pores are migration routes for corrosive media, so a sealing stage is necessary to stabilize the $\mathrm{Al}_{2} \mathrm{O}_{3}$ layer, decrease pore size pores, and increase resistance to corrosion. There are different ways to perform the sealing treatment, which can be carried out through different solutions $[22,23]$. The best results of the sealing stage depend on the surface chemical reactivity of the porous oxide structure in the samples anodized [5,19-21]. One of the most widely known sealing stages is sodium dichromate $\left(\mathrm{Na}_{2} \mathrm{Cr}_{2} \mathrm{O}_{7}\right)$; it not only blocks the pores, but also provides inhibition [5,25-28].

The aim of this work was to evaluate the corrosion behavior of the AA2055 Aluminumlithium alloy anodized with sulfuric acid $\left(\mathrm{H}_{2} \mathrm{SO}_{4}\right)$, varying the current conditions 0.19 and $1 \mathrm{~A} \cdot \mathrm{cm}^{-2}$ and $\mathrm{H}_{2} \mathrm{O}$ and $\mathrm{Na}_{2} \mathrm{Cr}_{2} \mathrm{O}_{7}$ sealing solution. Electrochemical behavior was studied by electrochemical impedance spectroscopy (EIS) technique, and characterization of the oxide layer of aluminum was done using scanning electron microscopy (SEM) and X-ray photoelectron spectroscopy (XPS). Aluminum alloys in aircraft are exposed to different atmospheres such as marine and industrial (acid rain). Exposure to sulfuric acid can simulate an acid rain environment, which is formed from the chemical reactions of sulfur dioxide and nitrogen oxides found in the atmosphere with water and chemical contaminants that result in nitric and sulfuric acids [29].

\section{Materials and Methods}

\subsection{Metallographic Preparation of Samples}

The material used in this study was AA2055, which represents the third generation of the aluminum-lithium alloy. The nominal chemical composition of the AA2055 alloys is shown in Table 1.

Table 1. The nominal chemical composition of AA2055 alloy (wt.\%).

\begin{tabular}{cccccccccccc}
\hline \multirow{2}{*}{ Alloy } & \multicolumn{10}{c}{ Elements } \\
\cline { 2 - 10 } & $\mathbf{C u}$ & $\mathbf{L i}$ & $\mathbf{Z n}$ & $\mathbf{A g}$ & $\mathbf{M g}$ & $\mathbf{M n}$ & $\mathbf{Z r}$ & $\mathbf{F e}$ & $\mathbf{S i}$ & $\mathbf{A l}$ \\
\hline 2055 & $3.2-4.2$ & $1.0-1.3$ & $0.30-0.70$ & $0.20-0.70$ & $0.20-0.60$ & $0.10-0.50$ & $0.05-0.15$ & 0.1 max & 0.07 max & Balance \\
\hline
\end{tabular}

The aluminum samples were mechanically polished using metallographic techniques according to ASTM E3 [30]. The material was sequentially polished using different SiC grit 
papers with 400,600 , and 800 grades, followed by ultrasonic cleaning in ethanol $\left(\mathrm{C}_{2} \mathrm{H}_{5} \mathrm{OH}\right)$ and deionized water.

\subsection{Anodizing Treatment}

The anodizing treatment consisted of the following stages [31]:

- Pretreatment:

- Degreased and Pickling in a $50 \mathrm{wt} . \% \mathrm{HCl}$ solution (analytical grade reagents (J.T. Baker, Nuevo León, México) for $5 \mathrm{~s}$ at $25^{\circ} \mathrm{C}$

Rinsed in distilled water

- Anodizing treatment:

Bath $=16 \mathrm{wt} . \% \mathrm{H}_{2} \mathrm{SO}_{4}$ solution (analytical grade reagents (J.T. Baker))

Current densities $=0.19$ and $1.0 \mathrm{~A} \cdot \mathrm{cm}^{-2}$

Electrolyte $\mathrm{pH}=6.0$

Time $=45 \mathrm{~min}$

Temperature $=25^{\circ} \mathrm{C}$

- Sealing treatment:

0 The anodized specimens were immersed in $\mathrm{H}_{2} \mathrm{O}$ or in $6 \mathrm{wt} . \% \mathrm{Na}_{2} \mathrm{Cr}_{2} \mathrm{O}_{7}$ solution (analytical grade reagents (J.T. Baker)) at $95{ }^{\circ} \mathrm{C}$ for $25 \mathrm{~min}$.

Table 2 shows the nomenclature of different samples (S).

Table 2. Nomenclature and anodizing conditions of different samples.

\begin{tabular}{|c|c|c|c|c|c|}
\hline \multirow{2}{*}{ Alloy } & \multirow{2}{*}{ Nomenclature } & \multicolumn{3}{|c|}{ Sealing Treatment } & \multirow{2}{*}{$\begin{array}{c}\text { Anodizing } \\
\text { Current Density } \\
\left(\mathrm{A} \cdot \mathrm{cm}^{2}\right)\end{array}$} \\
\hline & & Temperature $\left({ }^{\circ} \mathrm{C}\right)$ & Time (min) & Solution & \\
\hline \multirow{4}{*}{ AA2055 } & S1 & - & - & - & 0.19 \\
\hline & $\mathrm{S} 2$ & 95 & - & $\mathrm{H}_{2} \mathrm{O}$ & 1.00 \\
\hline & S3 & - & 25 & - & 0.19 \\
\hline & S4 & - & - & 6 wt. $\% \mathrm{Na}_{2} \mathrm{Cr}_{2} \mathrm{O}_{7}$ & 1.00 \\
\hline
\end{tabular}

\subsection{SEM Characterization}

Microstructural analysis of the surface and in cross sections was done using scanning electron microscope (SEM, JEOL-JSM-5610LV, Tokyo, Japan), operating at $20 \mathrm{KV}$ and a work distance of $12 \mathrm{~mm}$. The surface micrographs by SEM was done using a secondary electrons (SE) detector. Observations of micrographs of the oxide layer thickness in cross sections were done using a backscattered electrons (BSE) detector.

\subsection{Electrochemical Impedance Spectroscopy}

EIS measurements were conducted at room temperature using an electrochemical Interface mod. 1287A and Impedance Analyzer mod. 1260 Solartron (Bognor Regis, UK) in 10 vol. $\% \mathrm{H}_{2} \mathrm{SO}_{4}$ solution [32-34].

EIS measurements parameters were used in the frequency range from $100 \mathrm{kHz}$ to $1 \mathrm{mHz}$, with an amplitude of $10 \mathrm{mV}$ sinewave $[35,36]$. The impedance data were collected and modelled using ZPlot and ZView software (Zview 2.0 software), respectively (Scribner Associates, Southern Pines, NC, USA). Corrosion tests were conducted in triplicate.

\subsection{XPS Characterization}

XPS analyses were performed to determine the chemical composition of the aluminum oxide layer and were done using the Thermo Fisher Scientific ESCALAB 250 Xi equipment (Waltham, MA, USA) at a pressure of approximately $10 \mathrm{mBar}$; the excitation of the analyzed photoelectrons was carried out with a monochromatic Al KAlpha X-ray source (1486 eV), analysis radius of $\mu \mathrm{m}$, as well as the analysis conditions for the high-resolution zones (eV step energy, $45^{\circ}$ of "take-off angle" with $0.1 \mathrm{eV}$ step). 


\section{Results and Discussion}

\subsection{SEM Microstructural Analysis}

The SEM-analyzed micrographs of the oxide layer of AA2055 alloy anodized is of great importance for the corrosion behavior.

Figure 1 shows the surface micrographs by SEM using a secondary electrons (SE) detector for the AA2055 anodized samples (S1, S2, S3, and S4) at different current densities (0.19 and $1 \mathrm{~A} \cdot \mathrm{cm}^{-2}$ ) and sealing in $\mathrm{H}_{2} \mathrm{O}$ and $\mathrm{Na}_{2} \mathrm{Cr}_{2} \mathrm{O}_{7}$ solutions. Figure 1a shows a heterogeneous surface compared to the superficial micrographs of Figure $1 \mathrm{~b}-\mathrm{d}$. In the surface micrographs of sample S1, there are areas with a series of bumps and some bright precipitations derived from substrate elements and impurities. Herrera et al. [37] mentioned that these impurities affect the homogeneity of the passive layer and are present because they were not completely removed during mechanical polishing or in the stage prior to anodizing. Some authors $[17,38,39]$ have reported that the micrometric scale defects present on the surface of the anodic film have had a similar behavior in the AA2099 alloy due to the high copper content. Figure 1c,d shows samples S3 and S4 with some imperfections (cavity) on the surface; this may be due to varying the current density, the sealing solutions and the preferential dissolution of intermetallic phases, during the growth of the $\mathrm{Al}_{2} \mathrm{O}_{3}$ layer in the $\mathrm{H}_{2} \mathrm{SO}_{4}$ bath, resulting in a no-uniform surface [40].
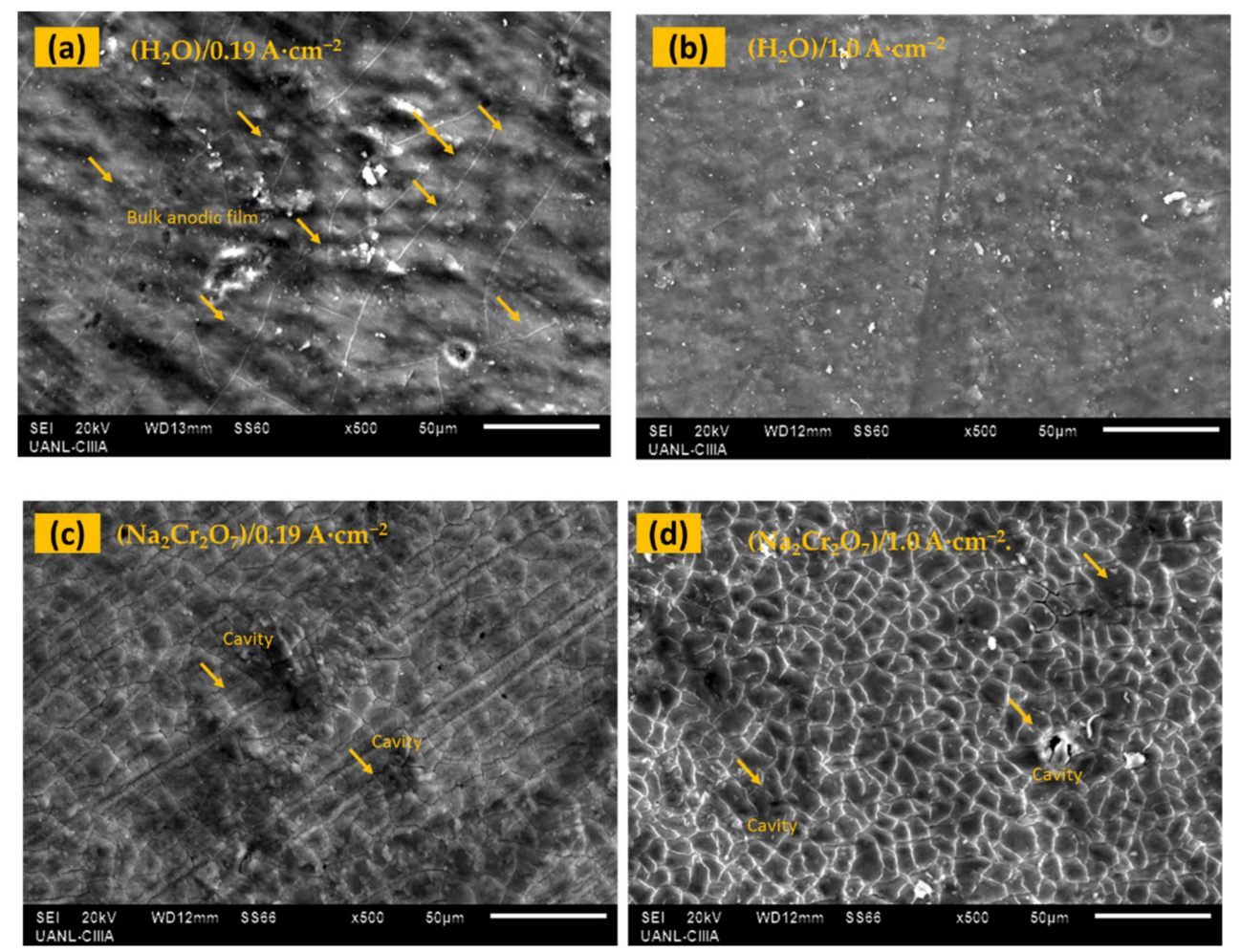

Figure 1. SEM-SEI surface micrographs of the anodized AA2055 alloys with different sealing treatments: (a) S1, (b) S2, (c) S3, and (d) S4.

Figure 2 shows the micrographs obtained by scanning electron microscope using a backscattered electrons (BSE) detector for cross section anodized samples and their average thickness of the anodic oxide film. The current density of 0.19 and $1 \mathrm{~A} \cdot \mathrm{cm}^{-2}$ did not influence the oxide film; homogeneity is observed in all samples. The average thickness in the anodized samples is between 4.33 and $5.41 \mu \mathrm{m}$. The thickness of the aluminum oxide layer of coating greatly depends on the current density, the bath, and the time of anodization [41]. 

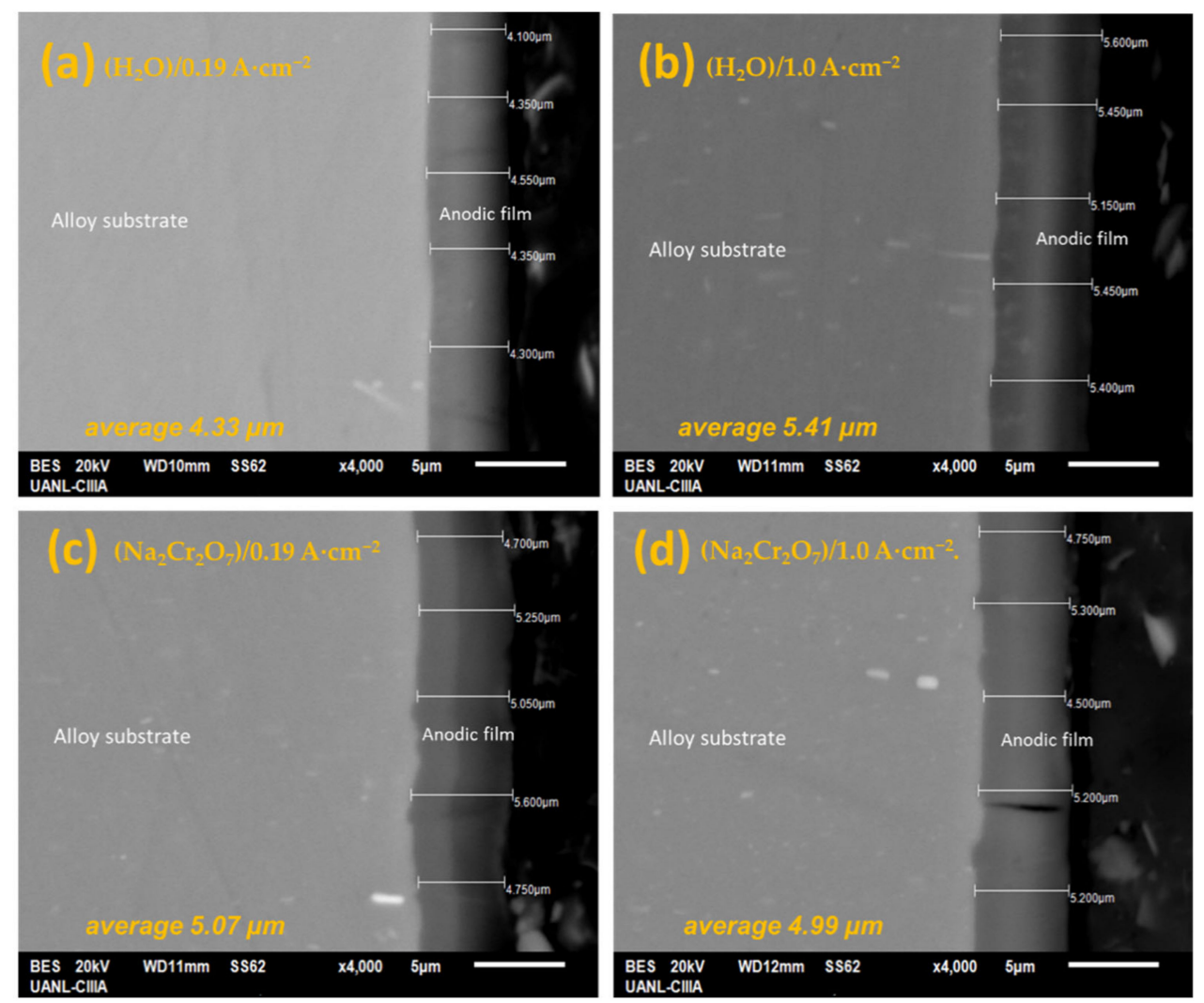

Figure 2. SEM-BES cross-sectional micrographs of the anodized AA2055 samples with different sealing treatments: (a) S1, (b) S2, (c) S3, and (d) S4.

\subsection{Electrochemical Impedance Spectroscopy Analysis}

Figure 3 shows Nyquist diagrams, for anodized and sealed Al-Li AA2055 alloy immersed in 10 vol. $\% \mathrm{H}_{2} \mathrm{SO}_{4}$ solution. In all samples, a capacitive loop is observed at high frequencies, at intermedium frequencies, it observed a capacitive behavior, and finally, in low frequency, we see an inductive loop having origin at frequencies between 0.20 and $0.01 \mathrm{~Hz}$, which is presented in the fourth quadrant. The two capacitive loops associated at high and intermediate frequencies can be related to the ingress of the corrosive medium through the surface of the anodic coating. This is due to the surface defects seen in Figures 1 and 2, which in some cases extend to the surface of the metallic substrate. For the inductive loop observed at low frequencies, some authors have proposed different origins, among which it may be attributed to the disturbance induced by redissolution of the oxide layer formed in the anodizing process, to the species adsorption-desorption processes and related to the existence of a passive current [42-44]. According to Bastidas, Jirón, Jinlong, and Alexe [45-49], the adsorption-desorption processes on the anodized surface origin negative values of capacitance and resistance. Information provided by the diameter of the semicircle corresponding to resistance of the process is occurring [50-55]. 

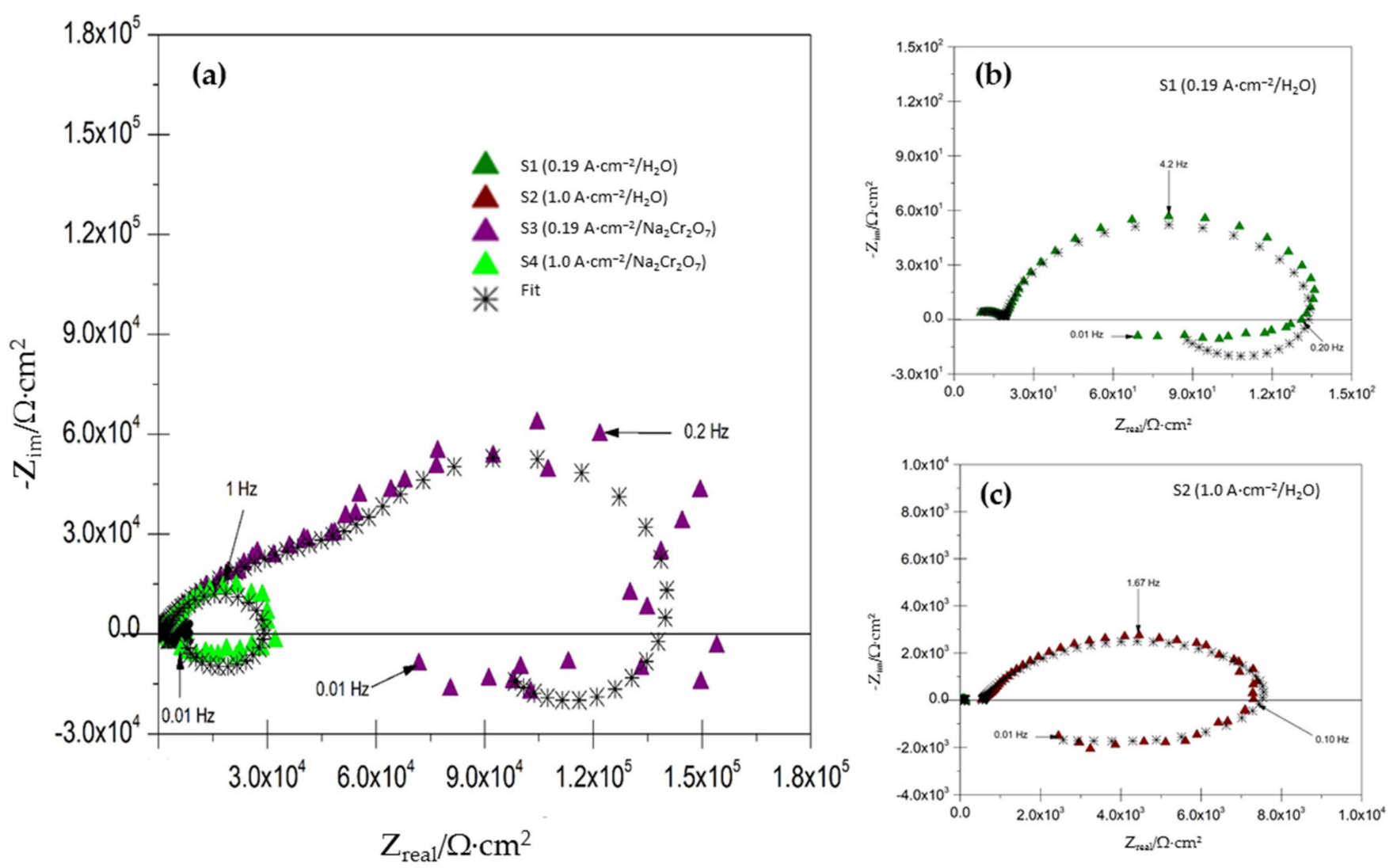

Figure 3. Nyquist diagrams of anodized AA2055 samples immersed to 10 vol. $\% \mathrm{H}_{2} \mathrm{SO}_{4}$ : (a) S1-S4, (b) S1 and (c) S2.

Because of the presence of heterogeneities in barrier and porous layers, their capacitive behavior is better simulated by constant phase elements (CPE) than by a simple capacitance (C) of the electrochemical mechanism by interfacial charge storage. Fitting of the impedance data was accomplished using the equivalent circuit shown in Figure 4. Using this software (Zview 2.0 by Scribner Associates, Southern Pines, NC, USA), all the circuit parameters were adjusted simultaneously in order to fit the measured data and to obtain resistances, capacitances, relaxation frequencies, and the equivalent circuit of the materials under study. The impedance response provided by the equivalent circuit models simulates the experimental data accurately. As a result of the impedance measurements obtained, threetime constants are identified, which were adjusted using the equivalent electrical circuit model (EEC). Using CPE generally, increases in fit [56-59] and in corrosion studies, CPE are more often used to describe the frequency dependence of non-ideal capacitive behavior. Below is a CPE defined as according to the mathematical definition by Equation (1):

$$
\mathrm{Z}_{\mathrm{CPE}}=\frac{1}{\mathrm{Y}(\mathrm{j} \omega)^{\mathrm{n}}}
$$

where $\mathrm{Y}=$ admittance (the reciprocal of electrochemical impedance), $\mathrm{j}^{\mathrm{n}}=(-1)=$ imaginary number, $\omega=$ angular frequency, and $n=$ dimensionless fraction exponent $(-1<\mathrm{n}<+1)$. CPE is an ideal capacitor $(n=+1)$ and is an inductor $(n=-1)[45,54,60-67]$. The electrical processes at layers in anodized samples have been related to the EEC model that contains the electrolyte resistance (Rs), resistance due to the sealing effect is a parallel combination (R1//CPE1); R1 is in series with a second R2//CPE2 for resistance of the porous layer; and, finally, resistance (R3) and a constant phase element (CPE3) correspond to resistance of the barrier layer. 


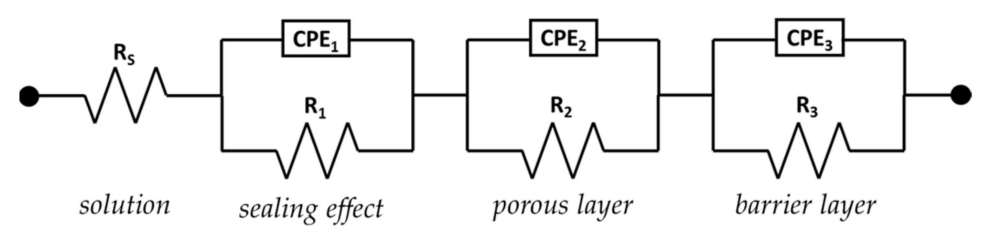

Figure 4. The proposed electrical equivalent circuit (EEC) model.

Table 3 shows the EIS measurements obtained by EEC simulation of AA2055 AluminumLithium alloys anodized and exposed to 10 vol. $\% \mathrm{H}_{2} \mathrm{SO}_{4}$ solutions. In the samples (S1-S4), the $\chi^{2}$ values are in the interval of $1.48 \times 10^{-2}-9.49 \times 10^{-3}$ represented, and the simulations carried out by the proposed equivalent circuit can be used. The variation of resistance solution (Rs) value in the interval of $4.6490-520.9189 \Omega \cdot \mathrm{cm}^{2}$ is due in most cases to the morphology of the anodic layer, which is associated with the surface charge and the double electrochemical layer generated between the electrolyte and the surface [68]. $Y_{1}, Y_{2}$, and $Y_{3}$ stand for sealing effect admittance, porous layer admittance, and barrier layer admittance, respectively in the ECC. The values of the resistance $R_{1}$, which are in an interval of 14.78 to $4121 \Omega \cdot \mathrm{cm}^{2}$, correspond to the sealing effect; $R_{2}$ have a value of 128 to $208,920 \Omega \cdot \mathrm{cm}^{2}$, which represents the resistance of the porous layer, and finally, $R_{3}$ with values of -66.77 to $-67,814 \Omega \cdot \mathrm{cm}^{2}$ is the resistance of the barrier layer. The resistance to charge transfer (Rct) is the sum of the absolute value of the resistances $R_{1}, R_{2}$, and $R_{3}$, which can be directly related to the corrosion resistance of the anodic layers formed during the anodizing process and sealing solution. In samples $S 3$ and $S 4$, the high resistance values $\left(R_{1}, R_{2}\right.$, and $\left.R_{3}\right)$ were presented, which indicates that sealing in $\mathrm{Na}_{2} \mathrm{Cr}_{2} \mathrm{O}_{7}$ solution produces anodic layers more resistant to corrosion. This behavior is related in some articles to the formation of compounds between the aluminum oxide and the chromium present in the sealing solution, benefiting the corrosion resistance properties of the film formed. Compounds formed in the sodium dichromate sealing process can be aluminum oxydichromate $\left[\mathrm{Al}(\mathrm{OH}) \mathrm{CrO}_{4}\right]$, or aluminum oxychromate $\left.\left[(\mathrm{AlO})_{2} \mathrm{CrO}_{4}\right)\right]$, which are formed in the micropores; additionally the residual hexavalent chromium acts as a corrosion inhibitor [69-71]. The highest values of Rct were present in sample S3 (anodized with $0.19 \mathrm{~A} \cdot \mathrm{cm}^{-2}$ and sealed with $\mathrm{Na}_{2} \mathrm{Cr}_{2} \mathrm{O}_{7}$ solution) and the lowest values were for sample $\mathrm{S} 2\left(\mathrm{H}_{2} \mathrm{O}\right.$ sealing solution), which can be due to the porosity of the aluminum oxide layer, which does not completely reduce the diameter of the pore when it is sealed with water. The $\mathrm{n}_{1}$ value is medium (0.6290-0.7961), the significance of a homogeneous surface of the anodic oxide layer. The $\mathrm{n}_{2}$ value is high (0.5585-0.9032), indicating a producing depressed semicircle, which may be attributed to the homogeneity of the porous layer, and the $n_{3}(0.5390-0.7795)$ parameter value is medium-high, which may be attributed to the homogeneity of the barrier layer [69-74]. The negative values of $R_{3}$ and $Y_{3}$ that correspond to the barrier layer can be explained as follows: negative capacitance occurs when the surface layer generated by different species on the surface decreases and the negative resistance is due to the interaction between the adsorption and electrodissolution of the oxide layer; negative resistances can also occur in a passive-active transition of electrochemical systems, and these negative values of capacitance and resistance occur when the systems are unstable [75-79].

Table 3. EIS measurements obtained by EEC simulation of AA2055 aluminum-lithium alloys.

\begin{tabular}{|c|c|c|c|c|c|c|c|c|c|c|c|}
\hline Samples & $\begin{array}{c}R_{s} \\
\left(\Omega \cdot \mathrm{cm}^{2}\right)\end{array}$ & $\begin{array}{c}R_{1} \\
\left(\Omega \cdot \mathrm{cm}^{2}\right)\end{array}$ & $\begin{array}{c}Y_{1} \\
\left(\mu s^{n 1} \cdot \mathrm{cm}^{-2}\right)\end{array}$ & $n_{1}$ & $\begin{array}{c}R_{2} \\
\left(\Omega \cdot \mathrm{cm}^{2}\right)\end{array}$ & $\begin{array}{c}\mathrm{Y}_{2} \\
\left(\mu \Omega \mathrm{s}^{\mathrm{n} 2} \cdot \mathrm{cm}^{-2}\right)\end{array}$ & $n_{2}$ & $\begin{array}{c}R_{3} \\
\left(\Omega \cdot \mathrm{cm}^{2}\right)\end{array}$ & $\begin{array}{c}\mathrm{Y}_{3} \\
\left(\mu \Omega \mathrm{s}^{n 3} \cdot \mathrm{cm}^{-2}\right)\end{array}$ & $n_{3}$ & $X^{2}$ \\
\hline S1 & $\begin{array}{c}4.6490 \pm \\
0.23\end{array}$ & $\begin{array}{c}14.78 \pm \\
0.73\end{array}$ & $\begin{array}{c}19.4996 \pm \\
0.97\end{array}$ & 0.6637 & $\begin{array}{c}128 \pm \\
6.40\end{array}$ & $\begin{array}{c}462.4946 \pm \\
23.12\end{array}$ & 0.9032 & $\begin{array}{l}-66.77 \\
\pm 3.33\end{array}$ & $\begin{array}{l}-0.000275 \pm \\
1.37 \times 10^{-5}\end{array}$ & 0.7724 & $\begin{array}{c}9.49 \times \\
10^{-3}\end{array}$ \\
\hline S2 & $\begin{array}{c}520.9189 \\
\pm 26.04\end{array}$ & $\begin{array}{c}1459 \pm \\
72.95\end{array}$ & $\begin{array}{c}22.1623 \pm \\
1.10\end{array}$ & 0.6725 & $\begin{array}{c}7680 \pm \\
384\end{array}$ & $\begin{array}{c}9.7601 \pm \\
0.48\end{array}$ & 0.7725 & $\begin{array}{c}-7452 \pm \\
372.6\end{array}$ & $\begin{array}{c}-319.4101 \\
15.97\end{array} \pm$ & 0.7795 & $\begin{array}{c}8.95 \times \\
10^{-3}\end{array}$ \\
\hline S3 & $\begin{array}{c}60.9330 \\
\pm 3.04\end{array}$ & $\begin{array}{l}4121 \pm \\
206.05\end{array}$ & $\begin{array}{c}0.2807 \pm \\
0.01\end{array}$ & 0.7961 & $\begin{array}{c}208,920 \\
\pm 10,446\end{array}$ & $\begin{array}{c}3.2972 \pm \\
0.16\end{array}$ & 0.5585 & $\begin{array}{l}-67,814 \\
\pm 3390.7\end{array}$ & $\begin{array}{c}-2.0652 \pm \\
0.10\end{array}$ & 0.5788 & $\begin{array}{c}1.65 \times \\
10^{-2}\end{array}$ \\
\hline S4 & $\begin{array}{c}20.6851 \\
\pm 1.03\end{array}$ & $\begin{array}{c}1770 \pm \\
88.50\end{array}$ & $4.1416 \pm 0.20$ & 0.6290 & $\begin{array}{l}47,900 \pm \\
2395\end{array}$ & $\begin{array}{c}9.8849 \\
0.49\end{array}$ & 0.6653 & $\begin{array}{c}-35,940 \\
\pm 1797\end{array}$ & $\begin{array}{c}-0.4468 \pm \\
0.02\end{array}$ & 0.5390 & $\begin{array}{c}1.48 \times \\
10^{-2}\end{array}$ \\
\hline
\end{tabular}




\subsection{XPS Surface Analysis}

To determine the surface chemical composition of the oxide layer and valence states in the Al-Li AA2055 alloy, anodized the samples were investigated by XPS, as shown in Figures 5 and 6 . Spectral analysis was performed using Avantage software of Thermo Fisher Scientific equipment (Waltham, MA, USA). To carry out chemical analysis, it is necessary to make the calculations of the deconvolution or contributions that the experimental spectrum contains, and assignment of the elements or compounds is through the peaks binding energy (they may be simple, doublets/satellites) using the database NIST (National Institute of Standards and Technology; Gaithersburg, MD, USA).

Figures 5 and 6 show high-resolution XPS spectra that were collected for $\mathrm{Al} 2 \mathrm{p}$ and O 1s. X-ray photoelectron spectra for $\mathrm{Al} 2 \mathrm{p}$ are shown in Figure $5 \mathrm{a}-\mathrm{d}$. Five chemical species found $\mathrm{Al}_{2} \mathrm{O}_{3}, \mathrm{Al}_{2} \mathrm{~S}_{3}, \mathrm{Al}_{2} \mathrm{SiO}_{5}, \mathrm{Al}(\mathrm{OH})_{3}, \mathrm{Al}(\mathrm{OH})$, and $\mathrm{Cr}_{2} \mathrm{O}_{3}$. The binding energy range for the high-resolution spectra for $\mathrm{Al} 2 \mathrm{p}$ where this behavior occurs is 73.85 to $76.88 \mathrm{eV}$; see the table of results of the parameters obtained from the peak binding energy and full width at half maximum (FWHM) fitting in Figure 5a'-d', respectively.

According to some authors, the peak of the binding energy of metallic aluminum is presented at $71.6 \mathrm{eV}$, which was not detected in the outer layer of the surface of the anodized aluminum of this work. However, the peaks of oxides and aluminum hydroxides (Figure 5) whit values approximate of $74.5 \mathrm{eV}$ [80]. For this reason, it can be considered the FWHM with a value of 0.99 in Figure $5 b^{\prime}$ related to the binding energy of 73.85 and $74.19 \mathrm{eV}$, corresponding to aluminum oxides and hydroxides, since the separation between the peaks of metallic aluminum and oxides and hydroxides have been reported with binding energy values of 2.5 and $3.7 \mathrm{eV}$, which depend on the thickness and the growth process of the oxide [81]. In the XPS spectra for $\mathrm{Al} 2 \mathrm{p}$, a displacement of the binding energy peaks is observed (Figure $5 b-d$ ); when there is an increase in the current of the anodizing process influences, the structure of the oxide of the samples under study is independent of the sealing solution [82]. In this investigation, the presence of $\mathrm{Cr}_{2} \mathrm{O}_{3}$ was detected in the samples sealed with $\mathrm{Na}_{2} \mathrm{Cr}_{2} \mathrm{O}_{7}$, this may be due to a migration process of the chromate ions into the interior of the Al oxide layer shown in Figures $5 \mathrm{c}$ and $6 \mathrm{c}, \mathrm{d}$. According to the literature [81-85], the non-detection of compound suggests that their concentration has not reached the necessary critical level, probably because they integrate very low solubility second-phase particulates instead of being in solid solution.

The contributions of $\mathrm{O} 1 \mathrm{~s}$ can be observed in the XPS spectra, where they reveal the typical binding energies for $\mathrm{O} 1 \mathrm{~s}$, from 530.62 to $532.8 \mathrm{eV}$ according to the Gauss-Lorentz peak (Figure 6a-d). The presence of oxygen in the form of aluminum oxide and hydroxides on the surface could be attributed to the presence of $\mathrm{OH}-$ and water groups by the sealing solutions, respectively.

The presence of $\mathrm{SiO}_{2}$ in the XPS spectra of the $\mathrm{O}$ 1s orbital, whose binding energy is between 531.28 and $533.59 \mathrm{eV}$, Figure $6 \mathrm{a}^{\prime}-\mathrm{d}^{\prime}$, can be attributed to different reasons such as: mechanical polishing, impurity in the anodizing bath or the sealing solution. In some works, different species have been found in the oxides produced by the anodizing process from aged baths; however, this difference was not significant in these works [40].

See table results of the parameters obtained, Figure $6 a-d ~[41,76-80]$.

XPS spectra for Al-Li AA2055 alloy: Figure 5-(a) element Al 2p for S1 sample, (b) Al 2p-S2, (c) Al 2p-S3, (d) Al 2p-S4, and Figure 6-(a) element O 1s-S1 sample, (b) O $1 \mathrm{~s}-\mathrm{S} 2$, (c) $\mathrm{O} 1 \mathrm{~s}-\mathrm{S} 3$, (d) $\mathrm{O} 1 \mathrm{~s}-\mathrm{S} 4$, of the chromate ions into the interior of the $\mathrm{Al}$ oxide layer [65]. The results of AA2055 specimens sealed $\mathrm{H}_{2} \mathrm{O}$ presented a surface film rich $\mathrm{Al}_{2} \mathrm{O}_{3}$ and $\mathrm{Al}(\mathrm{OH})$; this is attributed to the anodizing and sealing process, while for the $\mathrm{Na}_{2} \mathrm{Cr}_{2} \mathrm{O}_{7}$ sealing, the $\mathrm{Al}_{2} \mathrm{O}_{3}$ was the main aluminum oxide found on the surface [86-94]. 


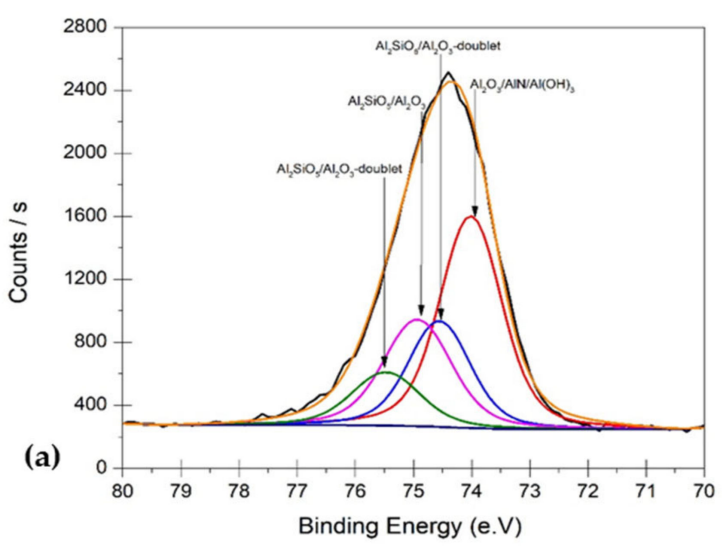

$\mathrm{S} 1\left(0.19 \mathrm{~A} \cdot \mathrm{cm}^{-2} / \mathrm{H}_{2} \mathrm{O}\right)$

\begin{tabular}{|c|c|c|c|}
\hline Compound & $\begin{array}{c}\text { Peak } \\
\text { Binding } \\
\text { Energy } \\
\text { (e.V) }\end{array}$ & $\begin{array}{c}\text { Area } \\
\text { Ratio }\end{array}$ & $\begin{array}{c}\text { FWHM fit } \\
\text { param } \\
\text { (eV) }\end{array}$ \\
\hline $\mathrm{Al}_{2} \mathrm{O}_{3} / \mathrm{AlN} / \mathrm{Al}(\mathrm{OH})_{3}$ & 74.02 & 1 & 1.26 \\
\hline $\begin{array}{c}\mathrm{Al}_{2} \mathrm{O}_{3} / \mathrm{AlN} / \mathrm{Al}(\mathrm{OH})_{3}{ }^{-} \\
\text {doublet }\end{array}$ & 74.56 & 0.5 & 1.26 \\
\hline $\mathrm{Al}_{2} \mathrm{SiO}_{5} / \mathrm{Al}_{2} \mathrm{O}_{3}$ & 74.93 & 0.55 & 1.38 \\
\hline $\begin{array}{c}\mathrm{Al}_{2} \mathrm{SiO}_{5} / \mathrm{Al}_{2} \mathrm{O}_{3^{-}} \\
\text {doublet }\end{array}$ & 75.47 & 0.28 & 1.38 \\
\hline
\end{tabular}

(a')

$\mathrm{S} 2\left(1.0 \mathrm{~A} \cdot \mathrm{cm}^{-2} / \mathrm{H}_{2} \mathrm{O}\right)$

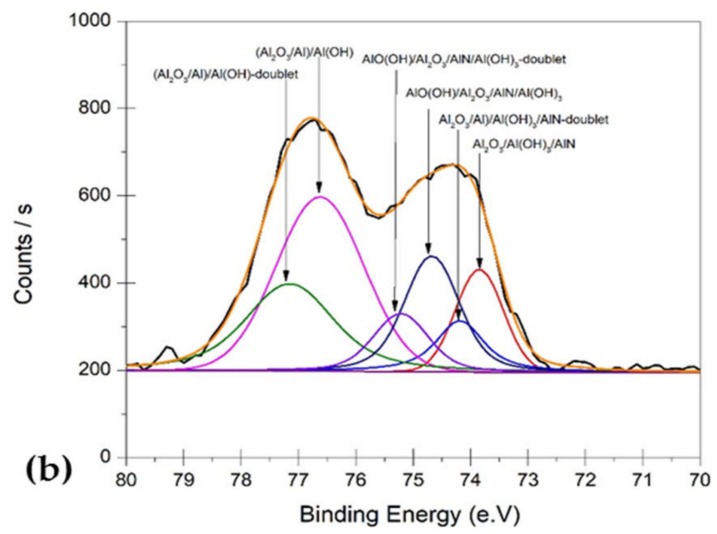

\begin{tabular}{|c|c|c|c|}
\hline Compound & $\begin{array}{c}\text { Peak } \\
\text { Binding } \\
\text { Energy } \\
\text { (e.V) }\end{array}$ & $\begin{array}{c}\text { Area } \\
\text { Ratio }\end{array}$ & $\begin{array}{c}\text { FWHM fit } \\
\text { param } \\
\text { (eV) }\end{array}$ \\
\hline $\mathrm{Al}_{2} \mathrm{O}_{3} / \mathrm{Al}(\mathrm{OH})_{3} / \mathrm{AlN}$ & 73.85 & 0.32 & 0.99 \\
\hline $\begin{array}{c}\mathrm{Al}_{2} \mathrm{O}_{3} / \mathrm{Al}(\mathrm{OH}) 3 / \mathrm{AlN}- \\
\text { doublet }\end{array}$ & 74.19 & 0.22 & 0.99 \\
\hline$\left(\mathrm{Al}_{2} \mathrm{O}_{3} / \mathrm{Al}\right) / \mathrm{Al}(\mathrm{OH})$ & 76.62 & 1 & 1.8 \\
\hline $\begin{array}{c}\left(\mathrm{Al}_{2} \mathrm{O}_{3} / \mathrm{Al}\right) / \mathrm{Al}(\mathrm{OH})- \\
\text { doublet }\end{array}$ & 77.15 & 0.59 & 1.8 \\
\hline $\begin{array}{c}\mathrm{AlO}(\mathrm{OH}) / \mathrm{Al}_{2} \mathrm{O}_{3} / \mathrm{AlN} \\
/ \mathrm{Al}(\mathrm{OH})_{3}\end{array}$ & 74.68 & 0.46 & 1.13 \\
\hline $\begin{array}{c}\mathrm{AlO}(\mathrm{OH}) / \mathrm{Al}_{2} \mathrm{O}_{3} / \mathrm{AlN} \\
/ \mathrm{Al}(\mathrm{OH})_{3}-\mathrm{doublet}\end{array}$ & 75.22 & 0.23 & 1.13 \\
\hline
\end{tabular}

(b')

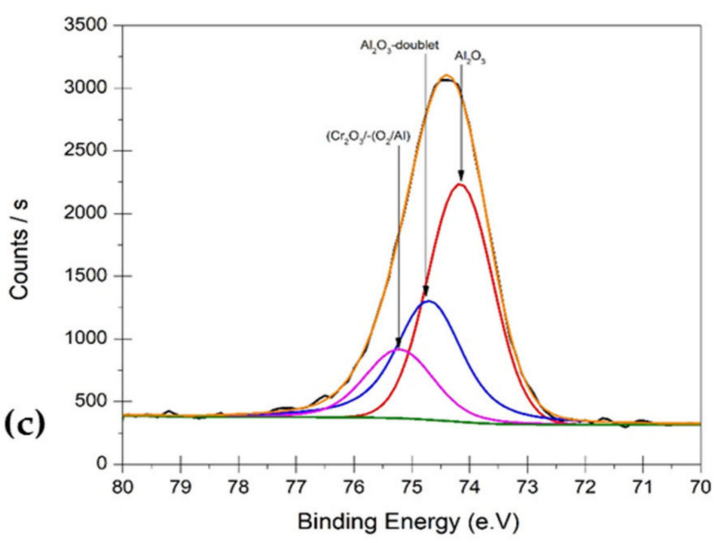

S3 $\left(0.19 \mathrm{~A} \cdot \mathrm{cm}^{-2} / \mathrm{Na}_{2} \mathrm{Cr}_{2} \mathrm{O}_{7}\right)$

\begin{tabular}{|c|c|c|c|}
\hline Compound & $\begin{array}{c}\text { Peak } \\
\text { Binding } \\
\text { Energy } \\
\text { (e.V) }\end{array}$ & $\begin{array}{c}\text { Area } \\
\text { Ratio }\end{array}$ & $\begin{array}{c}\text { FWHM fit } \\
\text { param } \\
\text { (eV) }\end{array}$ \\
\hline $\mathrm{Al}_{2} \mathrm{O}_{3}$ & 74.16 & 1 & 1.34 \\
\hline $\mathrm{Al}_{2} \mathrm{O}_{3}$-doublet & 74.7 & 0.61 & 1.34 \\
\hline $\mathrm{Cr}_{2} \mathrm{O}_{3}-\left(\mathrm{O}_{2} / \mathrm{Al}\right)$ & 75.21 & 0.32 & 1.39 \\
\hline
\end{tabular}

(c')

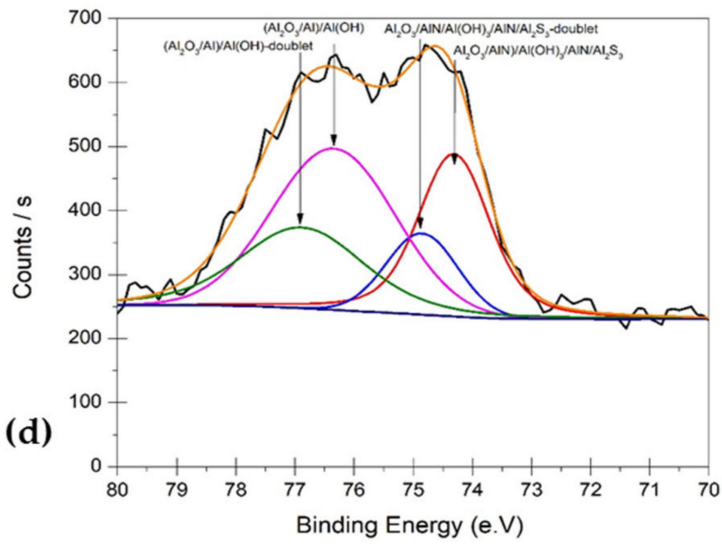

$\mathrm{S} 4\left(1.0 \mathrm{~A} \cdot \mathrm{cm}^{-2} / \mathrm{Na}_{2} \mathrm{Cr}_{2} \mathrm{O}_{7}\right)$

\begin{tabular}{|c|c|c|c|}
\hline Compound & $\begin{array}{c}\text { Peak } \\
\text { Binding } \\
\text { Energy } \\
\text { (e.V) }\end{array}$ & $\begin{array}{c}\text { Area } \\
\text { Ratio }\end{array}$ & $\begin{array}{c}\text { FWHM fit } \\
\text { param } \\
\text { (eV) }\end{array}$ \\
\hline $\begin{array}{c}\mathrm{Al}_{2} \mathrm{O}_{3} / \mathrm{AlN} / \mathrm{Al}(\mathrm{OH})_{3} / \\
\mathrm{AlN} / \mathrm{Al}_{2} \mathrm{~S}_{3}\end{array}$ & 74.31 & 0.66 & 1.42 \\
\hline $\begin{array}{c}\mathrm{Al}_{2} \mathrm{O}_{3} / \mathrm{AlN} / \mathrm{Al}(\mathrm{OH})_{3} / \\
\mathrm{AlN} / \mathrm{Al}_{2} \mathrm{~S}_{3} \text {-doublet }\end{array}$ & 74.85 & 0.29 & 1.42 \\
\hline$\left(\mathrm{Al}_{2} \mathrm{O}_{3} / \mathrm{Al}\right) / \mathrm{AlO}(\mathrm{OH})$ & 76.34 & 1 & 2.45 \\
\hline $\begin{array}{c}\left(\mathrm{Al}_{2} \mathrm{O}_{3} / \mathrm{Al}\right) / \mathrm{AlO}(\mathrm{OH}) \\
\text {-doublet }\end{array}$ & 76.88 & 0.56 & 2.45 \\
\hline
\end{tabular}

(d')

Figure 5. X-ray photoelectron spectra for Al-Li AA2055 alloy anodized: (a) Al 2p/S1, (b) Al 2p/S2, (c) Al 2p/S3, (d) Al

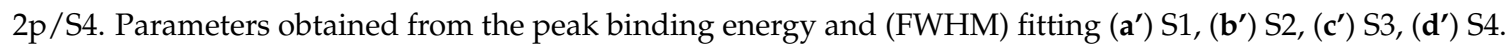




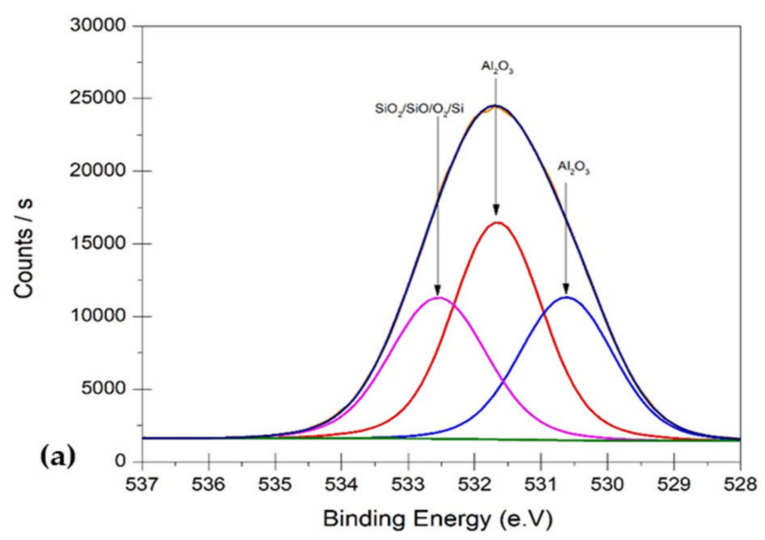

$\mathrm{S} 1\left(0.19 \mathrm{~A} \cdot \mathrm{cm}^{-2} / \mathrm{H}_{2} \mathrm{O}\right)$

\begin{tabular}{|l|c|c|c|}
\hline \multicolumn{1}{|c|}{ Compound } & $\begin{array}{c}\text { Peak } \\
\text { Binding } \\
\text { Energy } \\
\text { (e.V) }\end{array}$ & $\begin{array}{c}\text { Area } \\
\text { Ratio }\end{array}$ & $\begin{array}{c}\text { FWHM fit } \\
\text { param } \\
\text { (eV) }\end{array}$ \\
\hline $\mathrm{Al}_{2} \mathrm{O}_{3}$ & 531.65 & 1 & 1.59 \\
\hline $\mathrm{Al}_{2} \mathrm{O}_{3}$ & 530.62 & 0.68 & 1.66 \\
\hline $\mathrm{SiO}_{2} / \mathrm{SiO} /\left(\mathrm{O}_{2} / \mathrm{Si}\right)$ & 532.55 & 0.7 & 1.71 \\
\hline
\end{tabular}

(a')

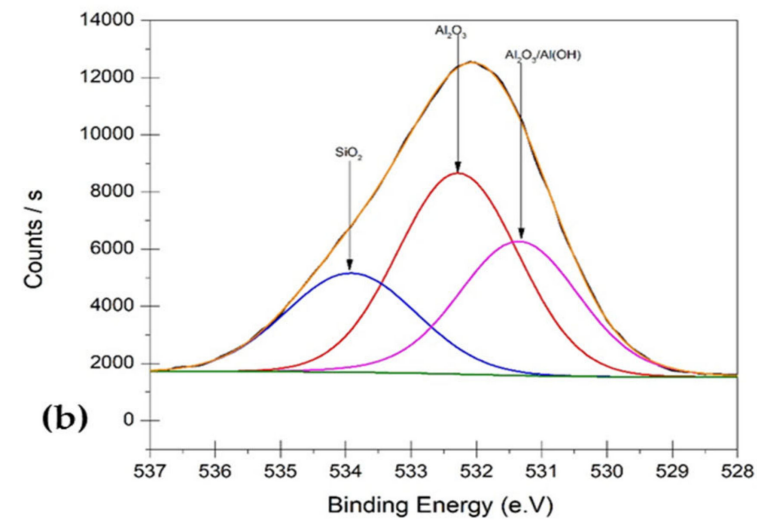

$\mathrm{S} 2\left(1.0 \mathrm{~A} \cdot \mathrm{cm}^{-2} / \mathrm{H}_{2} \mathrm{O}\right)$

\begin{tabular}{|l|c|c|c|}
\hline Compound & $\begin{array}{c}\text { Peak } \\
\text { Binding } \\
\text { Energy } \\
\text { (e.V) }\end{array}$ & $\begin{array}{c}\text { Area } \\
\text { Ratio }\end{array}$ & $\begin{array}{c}\text { FWHM fit } \\
\text { param } \\
\text { (eV) }\end{array}$ \\
\hline $\mathrm{Al}_{2} \mathrm{O}_{3}$ & 532.28 & 1 & 1.59 \\
\hline $\mathrm{Al}_{2} \mathrm{O}_{3} / \mathrm{Al}(\mathrm{OH})$ & 531.35 & 0.7 & 1.71 \\
\hline $\mathrm{SiO}_{2}$ & 533.92 & 0.68 & 1.66 \\
\hline
\end{tabular}

(b')

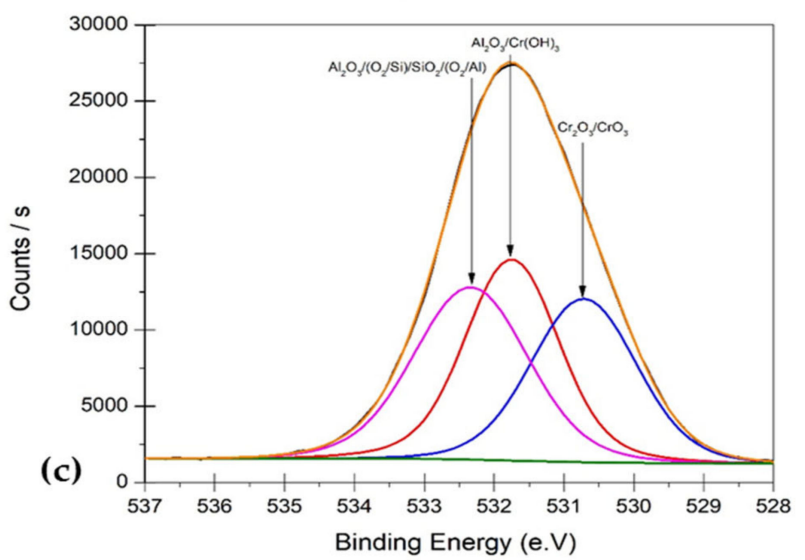

$\mathrm{S} 3\left(0.19 \mathrm{~A} \cdot \mathrm{cm}^{-2} / \mathrm{Na}_{2} \mathrm{Cr}_{2} \mathrm{O}_{7}\right)$

\begin{tabular}{|c|c|c|c|}
\hline Compound & $\begin{array}{c}\text { Peak } \\
\text { Binding } \\
\text { Energy } \\
\text { (e.V) }\end{array}$ & $\begin{array}{c}\text { Area } \\
\text { Ratio }\end{array}$ & $\begin{array}{c}\text { FWHM fit } \\
\text { param } \\
\text { (eV) }\end{array}$ \\
\hline $\mathrm{Al}_{2} \mathrm{O}_{3} / \mathrm{Cr}(\mathrm{OH})_{3}$ & 531.75 & 0.97 & 1.58 \\
\hline $\mathrm{Cr}_{2} \mathrm{O}_{3} / \mathrm{CrO}_{3}$ & 530.72 & 0.87 & 1.78 \\
\hline $\begin{array}{c}\mathrm{Al}_{2} \mathrm{O}_{3} /\left(\mathrm{O}_{2} / \mathrm{Si} / \mathrm{SiO}_{2} /\right. \\
\left(\mathrm{O}_{2} / \mathrm{Al}\right)\end{array}$ & 532.34 & 1 & 1.92 \\
\hline
\end{tabular}

(c')

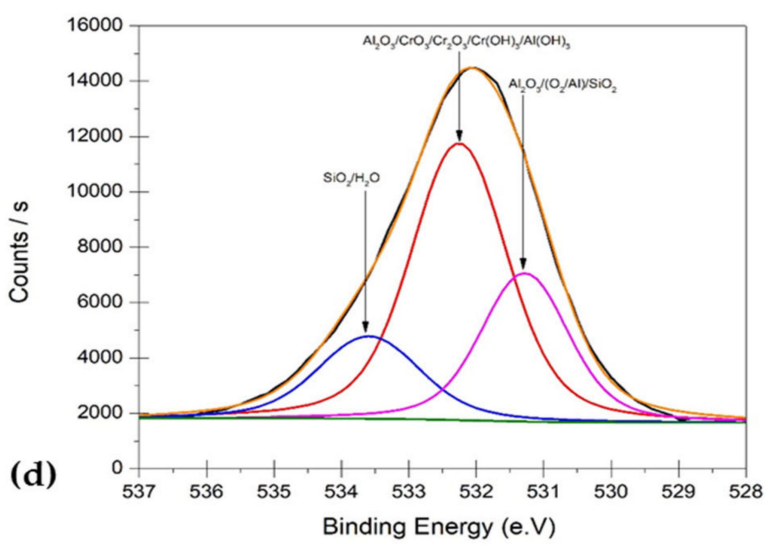

$\mathrm{S} 4\left(1.0 \mathrm{~A} \cdot \mathrm{cm}^{-2} / \mathrm{Na}_{2} \mathrm{Cr}_{2} \mathrm{O}_{7}\right)$

\begin{tabular}{|c|c|c|c|}
\hline Compound & $\begin{array}{c}\text { Peak } \\
\text { Binding } \\
\text { Energy } \\
\text { (e.V) }\end{array}$ & $\begin{array}{c}\text { Area } \\
\text { Ratio }\end{array}$ & $\begin{array}{c}\text { FWHM fit } \\
\text { param } \\
\text { (eV) }\end{array}$ \\
\hline $\mathrm{Al}_{2} \mathrm{O}_{3} /\left(\mathrm{O}_{2} / \mathrm{Al}\right) / \mathrm{SiO}_{2}$ & 531.28 & 0.49 & 1.53 \\
\hline $\mathrm{SiO}_{2} / \mathrm{H}_{2} \mathrm{O}$ & 533.59 & 0.32 & 1.79 \\
\hline $\begin{array}{l}\mathrm{Al}_{2} \mathrm{O}_{3} / \mathrm{CrO}_{3} / \mathrm{Cr}_{2} \mathrm{O}_{3} / \\
\mathrm{Cr}(\mathrm{OH})_{3} / \mathrm{Al}(\mathrm{OH})_{3}\end{array}$ & 532.26 & 1 & 1.68 \\
\hline
\end{tabular}

(d')

Figure 6. X-ray photoelectron spectra for Al-Li AA2055 alloy anodized: (a) O 1s /S1, (b) O 1s/S2, (c) O 1s/S3, (d) O 1s/S4. Parameters obtained from the peak binding energy and (FWHM) fitting ( $\left.\mathbf{a}^{\prime}\right) \mathrm{S} 1,\left(\mathbf{b}^{\prime}\right) \mathrm{S} 2,\left(\mathbf{c}^{\prime}\right) \mathrm{S} 3,\left(\mathbf{d}^{\prime}\right) \mathrm{S} 4$. 
The variations in the FWHM indicate changes in chemical state and physical influences. For example, if a peak broadening, corresponding to a possible change in the number of chemical bonds, that contributes to the shape of a peak, a change in sample conditions due to X-ray damage, or localized charge differences in the surface. Therefore, metals normally have lower FWHM values than metallic compounds [95]. There exist some substantial differences in the FWHM of the $\mathrm{Al} 2 \mathrm{p}$ peak, being narrower in the case of $\alpha-\mathrm{Al}_{2} \mathrm{O}_{3}(\mathrm{FWHM}$ of $1.35 \mathrm{eV}$ ), wider for hydroxides with FWHM values between 1.59 and $1.75 \mathrm{eV}$, and abnormally larger for $\gamma-\mathrm{Al}_{2} \mathrm{O}_{3}$ (FWHM of $2.46 \mathrm{eV}$ ) [96]. In this sense, we can see in Figure 5a' sample S1 that the FWHM values are close to the peak of the $\alpha-\mathrm{Al}_{2} \mathrm{O}_{3}$ compound, presenting values between 1.25 and $1.38 \mathrm{eV}$, while for Figure $5 \mathrm{~b}^{\prime}$, they present FWHM values of 0.99 to $1.13 \mathrm{eV}$, which would indicate the presence of $\alpha-\mathrm{Al}_{2} \mathrm{O}_{3}$ with a mixture of hydroxides, since there is an $\mathrm{O} 1 \mathrm{~s}$ peak of $1.8 \mathrm{eV}$ for sample S2. In the case of sample S3, Figure $5 \mathrm{c}^{\prime}$, only FWHM values between 1.34 and $1.39 \mathrm{eV}$ were observed, corresponding to $\alpha-\mathrm{Al}_{2} \mathrm{O}_{3}$. Finally, for sample S4, Figure $5 \mathrm{~d}^{\prime}$, there is a combination between $\alpha-\mathrm{Al}_{2} \mathrm{O}_{3}$ and $\gamma-\mathrm{Al}_{2} \mathrm{O}_{3}$ since the FWHM values are 1.42 and $2.45 \mathrm{eV}$ in the four peaks present.

Anodizing current density influences the compounds that can be formed during the process, since, as can be seen in Figure $5 a^{\prime}, c^{\prime}$, the compounds formed with current densities of $0.19 \mathrm{~A} \cdot \mathrm{cm}^{-2}$ correspond to $\alpha-\mathrm{Al}_{2} \mathrm{O}_{3}$, as observed in the FWHM values of samples S1 and S3. In Figure $5 b^{\prime}, d^{\prime}$, which were the anodized samples with a current density of $1 \mathrm{~A} \cdot \mathrm{cm}^{-2}$, there is the combination of $\alpha-\mathrm{Al}_{2} \mathrm{O}_{3}$ compounds, hydroxides, and $\gamma-\mathrm{Al}_{2} \mathrm{O}_{3}$ since the FWHM for samples S2 and S4 present values of $0.99,1.13,1.8$, and $2.45 \mathrm{eV}$. It is quite difficult to predictively calculate the $\mathrm{O} 1 \mathrm{~s}$ interval between oxide and hydroxide, but it is interesting to note that, in aluminum compounds $(\mathrm{Al}-\mathrm{O})$, the bond is approximately the same length for oxide and hydroxide bonds, while in most other elements, the hydroxide bond is higher. One way to distinguish between oxide, hydroxide, and water compounds is through analysis in the $\mathrm{O} 1 \mathrm{~s}$ region.

The $\mathrm{O} 1$ s peaks of aluminum oxides generally have values between 529 and $530 \mathrm{eV}$, which gives an interval of approximately $1 \mathrm{eV}$ to distinguish between aluminum oxide and hydroxide compounds. Aluminum hydroxides have higher binding energy than oxides, which are in a binding energy range for the $\mathrm{O} 1 \mathrm{~s}$ orbital between 0.5 and $0.75 \mathrm{eV}$. The usual values for the separation between oxide and hydroxide for most metals are in the interval of 1.5 to $2 \mathrm{eV}$, which makes it difficult to assign oxides and hydroxides in aluminum compounds [97]. In this work, O 1s peaks with binding energies from 530.62 to $532.34 \mathrm{eV}$ were presented, which limits the possibility of distinguishing between oxides and hydroxides in this orbital. For aluminum compounds, the differences between oxides and hydroxides cannot be easily distinguished, since any of the oxides may have a peak in the $\mathrm{O} 1 \mathrm{~s}$ orbital ( 529 to $530 \mathrm{eV}$ ). As can be seen in Figure $6 \mathrm{a}^{\prime}-\mathrm{d}^{\prime}$, all binding energies fall outside the range proposed in the literature for the oxide region [97]. The FWHM of all the $\mathrm{O} 1 \mathrm{~s}$ peaks is between 1.58 and $1.92 \mathrm{eV}$, giving a difference of $0.34 \mathrm{eV}$, which makes it difficult to assign aluminum oxide-hydroxide to the $\mathrm{O} 1$ s peaks.

\section{Conclusions}

- The results reveal that the EIS technique is a good tool for obtaining detailed information on the influence of sealing and the process on anodized aluminum.

- EIS results show that $\mathrm{R}_{2}$ increase for the sample $\mathrm{S}_{3}$ in presence of the $\mathrm{Na}_{2} \mathrm{Cr}_{2} \mathrm{O}_{7}$ sealing solution has a higher charge transfer resistance when it has a less homogeneous and less compact layer of anodic oxide.

- The inductive loop present in Nyquist diagrams for all samples indicates species on the surface decreases, adsorption and electrodissolution of the oxide on the AA2055 alloys anodized surface.

- The SEM and EIS results indicated that the formation of a more compact and homogeneous anodic oxide layer is due to an increase in charge transfer resistance $\left(\mathrm{R}_{\mathrm{CT}}\right)$, by preventing $\mathrm{Cl}^{-}$ions ingress into the anodized layer. 
- SEM characterization indicated that, in both current densities, the thickness is homogeneous for the oxide films formed on anodized AA2055 aluminum-lithium alloy. The surface micrographs indicated that samples have a heterogeneous surface with bumps, some bright precipitations, and cavity. This may be due to varying the current density and the sealing solutions during the growth of the $\mathrm{Al}_{2} \mathrm{O}_{3}$ layer in the $\mathrm{H}_{2} \mathrm{SO}_{4}$ bath.

- XPS characterization verified that the surface film of AA2055 alloy in this study consisted of a mixture of chemical compounds, such as $\mathrm{Al}_{2} \mathrm{O}_{3}$ and $\mathrm{AlO}(\mathrm{OH})$, respectively.

Author Contributions: Conceptualization, F.A.-C., P.O.S.-G. and C.G.-T.; methodology, J.C.-M., P.O.S.-G., L.D.L.-L., J.O.-C., L.G.S.V. and C.G.-T.; data curation, F.A.-C., L.G.S.V., E.M.-B., P.Z.-R., D.N.-M. and J.C-M; formal analysis, F.A.-C., P.O.S.-G. and C.G.-T.; writing-review and editing, F.A.-C., J.C.-M. and C.G.-T. All authors have read and agreed to the published version of the manuscript.

Funding: This research was funded by the Mexican National Council for Science and Technology (CONACYT) of the projects A1-S-8882 and the Universidad Autónoma de Nuevo León (UANL).

Institutional Review Board Statement: Not applicable.

Informed Consent Statement: Not applicable.

Data Availability Statement: The data presented in this study are available on request from the corresponding author.

Acknowledgments: The authors would like to thank the Mexican National Council for Science and Technology (CONACYT) for the support provided for the development of the projects A1-S-8882, the UANL-CA-316 working group and Universidad Autónoma de Nuevo León (UANL) for the facilities given to develop this investigation.

Conflicts of Interest: The authors declare no conflict of interest.

\section{References}

1. Saffari, H.; Sohrabi, B.; Noori, M.R.; Bahrami, H.R.T. Optimal condition for fabricating superhydrophobic aluminum surfaces with controlled anodizing processes. Appl. Surf. Sci. 2018, 435, 1322-1328. [CrossRef]

2. Jiang, B.; Yi, D.; Yi, X.; Zheng, F.; Wang, H.; Wang, B.; Hu, Z. Effect of trace amounts of added Sc on microstructure and mechanical properties of 2055 aluminum alloy. Mater. Charact. 2018, 141, 248-259. [CrossRef]

3. Keller, F.; Hunter, M.S.; Robinson, D.L. Structural features of oxide coatings on aluminum. J. Electrochem. Soc. 1953, 100, 411-419. [CrossRef]

4. Jaimes-Ramírez, R.; Covelo, A.; Rodil, S.E.; Corona-Lira, P.; Ramírez-Reivich, A.C.; Hernández, M. Development and characterization of hydrophobic anodized aluminum layer to act as a long-lasting protective film in corrosion. Surf. Interface Anal. 2018, 50, 1030-1035. [CrossRef]

5. Etienne, M.; Rocca, E.; Chahboun, N.; Veys-Renaux, D. Local evolution of $\mathrm{pH}$ with time determined by shear force-based scanning electrochemical microscopy: Surface reactivity of anodized aluminium. Electroanalysis 2016, 28, 2466-2471. [CrossRef]

6. Zhang, F.; Örnek, C.; Nilsson, J.-O.; Pan, J. Anodisation of aluminium alloy AA7075-influence of intermetallic particles on anodic oxide growth. Corros. Sci. 2020, 164, 108319. [CrossRef]

7. Ma, Y.; Chen, X.; Zhou, X.; Yi, Y.; Liao, Y.; Huang, W. Microstructural origin of localized corrosion in anodized AA2099-T8 aluminium-lithium alloy. Surf. Interface Anal. 2016, 48, 739-744. [CrossRef]

8. Mouritz, P.A. Introduction to Aerospace Materials; Woodhead Publishing: Cambridge, UK, 2012.

9. Zhou, X.R.; Meng, X.M.; Huang, W.J.; Yi, L.; Chen, X.L.; Yi, Y.N.; Thompson, G.E. Influence of thermomechanical treatments on localized corrosion susceptibility and propagation mechanism of AA2099 Al-Li alloy. Trans. Nonferrous Met. Soc. 2016, 26, 1472-1481. [CrossRef]

10. Gumbmann, E.; Lefebvre, W.; De Geuser, F.; Sigli, C.; Deschamps, A. The effect of minor solute additions on the precipitation path of an Al Cu Li alloy. Acta Mater. 2016, 115, 104-114. [CrossRef]

11. Gumbmann, E.; De Geuser, F.; Deschamps, A.; Lefebvre, W.; Robaut, F.; Sigli, C. A combinatorial approach for studying the effect of $\mathrm{Mg}$ concentration on precipitation in an Al-Cu-Li alloy. Scr. Mater. 2016, 110, 44-47. [CrossRef]

12. Ma, Y.; Zhou, X.; Huang, W.; Liao, Y.; Chen, X.; Zhang, X.; Thompson, G.E. Crystallographic defects induced localised corrosion in AA2099-T8 aluminium alloy. Corros. Eng. Sci. Technol. 2015, 50, 420-424. [CrossRef]

13. Deschamps, A.; Garcia, M.; Chevy, J.; Davo, B.; De Geuser, F. Influence of Mg and Li content on the microstructure evolution of Al $\mathrm{Cu}$ Li alloys during long-term ageing. Acta Mater. 2017, 122, 32-46. [CrossRef]

14. Deng, Y.; Bai, J.; Wu, X.; Huang, G.; Cao, L.; Huang, L. Investigation on formation mechanism of T1 precipitate in an Al-Cu-Li alloy. J. Alloys Compd. 2017, 723, 661-666. [CrossRef] 
15. Deschamps, A.; Decreus, B.; De Geuser, F.; Dorin, T.; Weyland, M. The influence of precipitation on plastic deformation of Al-Cu-Li alloys. Acta Mater. 2013, 61, 4010-4021. [CrossRef]

16. Eswara, P.N.; Gokhale, A.A.; Wanhill, H.J.R. Aluminium-Lithium: Processing, Properties and Applications; Butterworth-Heinemann; Elsevier Inc.: Waltham, MA, USA, 2014. [CrossRef]

17. Ma, Y.; Zhou, X.; Thompson, G.E.; Curioni, M.; Zhong, X.; Koroleva, E.; Fowles, M. Discontinuities in the porous anodic film formed on AA2099-T8 aluminium alloy. Corros. Sci. 2011, 53, 4141. [CrossRef]

18. Vignoli Machado, T.; Atz Dick, P.; Knörnschild, G.H.; Dick, L.F.P. The effect of different carboxylic acids on the sulfuric acid anodizing of AA2024. Surf. Coat. Technol. 2020, 383, 125283. [CrossRef]

19. Runge, J.M. The Metallurgy of Anodizing Aluminum; Springer: Chicago, IL, USA, 2018. [CrossRef]

20. Varshney, D.; Kumar, K. Application and use of different aluminium alloys with respect to workability, strength and welding parameter optimization. Ain Shams Eng. J. 2021, 12, 1143-1152. [CrossRef]

21. Ambor, M.; Nový, F.; Bokůvka, O.; Trško, L. The natural aging behavior of the AA 2055 Al-Cu-Li alloy. Transp. Res. Procedia 2019, 40, 42-45. [CrossRef]

22. Mopon, M.L., Jr.; Garcia, J.S.; Manguerra, D.M.; Narisma, C.J.C. Corrosion behavior of AA 1100 anodized in gallic-sulfuric acid solution. Coatings 2021, 11, 405. [CrossRef]

23. Raj, V.; Mumjitha, M. Comparative study of formation and corrosion performance of porous alumina and ceramic nanorods formed in different electrolytes by anodization. Mater. Sci. Eng. B Solid-State Mater. Adv. Technol. 2014, 179, 25-35. [CrossRef]

24. Martínez-Viademonte, M.P.; Abrahami, S.T.; Hack, T.; Burchardt, M.; Terryn, H. A review on anodizing of aerospace aluminum alloys for corrosion protection. Coatings 2020, 10, 1106. [CrossRef]

25. Cabral-Miramontes, J.; Gaona-Tiburcio, C.; Estupinán-López, F.; Lara-Banda, M.; Zambrano-Robledo, P.; Nieves-Mendoza, D.; Maldonado-Bandala, E.; Chacón-Nava, J.; Almeraya-Calderón, F. Corrosion resistance of hard coat anodized AA 6061 in citric-sulfuric solutions. Coatings 2020, 10, 601. [CrossRef]

26. Cabral-Miramontes, J.A.; Gaona-Tiburcio, C.; Almeraya-Calderón, F.; Estupiñan-Lopez, H.F.; Pedraza-Basulto, G.; Poblano-Salas, C. Parameter studies on high-velocity oxy-fuel spraying of CoNiCrAlY coatings used in the aeronautical industry. Int. J. Corros. 2014, 2014, 1-8. [CrossRef]

27. Zuo, Y.; Zhao, P.-H.; Zhao, J.-M. The influences of sealing methods on corrosion behavior of anodized aluminum alloys in NaCl solutions. Surf. Coat. Technol. 2003, 166, 237-242. [CrossRef]

28. Ko, C.-L.; Kuo, Y.-L.; Chen, S.-H.; Chen, S.-Y.; Guo, J.-Y.; Wang, Y.-J. Formation of aluminum composite passive film on magnesium alloy by integrating sputtering and anodic aluminum oxidation processes. Thin Solid Films 2020, 709, 138151. [CrossRef]

29. Gianni, L.; Cavallini, M.; Natali, S.; Adriaens, S. Wet and dry accelerated aging tests in a spray chamber to understand the effects of acid rain frequencies on bronze corrosion. Int. J. Electrochem. Sci. 2013, 8, 1822-1838.

30. ASTM E3-95. Standard Practice for Preparation of Metallographic Specimens; ASTM International: West Conshohocken, PA, USA, 1995.

31. Samaniego-Gámez, P.; Almeraya-Calderón, F.; Martin, U.; Ress, J.; Gaona-Tiburcio, C.; Silva-Vidaurri, L.; Cabral-Miramontes, J.; Bastidas, J.M.; Chacón-Nava, J.G.; Bastidas, D.M. Efecto del tratamiento de sellado en el comportamiento frente a corrosión de la aleación anodizada de aluminio-litio AA2099. Rev. Met. 2020, 56, e180. [CrossRef]

32. ASTM G106-15. Standard Practice for Verification of Algorithm and Equipment for Electrochemical Impedance Measurements; ASTM International: West Conshohocken, PA, USA, 2010.

33. Macdonald, D.D. Review of mechanistic analysis by electrochemical impedance spectroscopy. Electrochim. Acta 1990, 35, 1509-1525. [CrossRef]

34. Yang, Y.; Cheng, J.; Liu, S.; Wang, H.; Dong, P. Effect of $\mathrm{NaAlO}_{2}$ sealing on corrosion resistance of 2024 aluminum alloy anodized film. Mater. Corros. 2019, 70, 120-127. [CrossRef]

35. Cabral-Miramontes, J.; Bastidas, M.D.; Baltazar, M.A.; Zambrano-Robledo, P.; Bastidas, J.M.; Almeraya-Calderón, F.; GaonaTiburcio, C. Corrosion behavior of $\mathrm{Zn}-\mathrm{TiO}_{2}$ and $\mathrm{Zn}-\mathrm{ZnO}$ electrodeposited coatings in $3.5 \% \mathrm{NaCl}$ solution. Int. J. Electrochem. Sci. 2019, 14, 4226-4239. [CrossRef]

36. Gaona-Tiburcio, C.; Montoya-Rangel, M.; Cabral-Miramontes, J.A.; Estupiñan-López, F.; Zambrano-Robledo, P.; Orozco Cruz, R.; Chacón-Nava, J.G.; Baltazar-Zamora, M.A.; Almeraya-Calderón, F. Corrosion resistance of multilayer coatings deposited by PVD on Inconel 718 using electrochemical impedance spectroscopy technique. Coatings 2020, 10, 521. [CrossRef]

37. Herrera-Hernandez, H.; Vargas-Garcia, J.R.; Hallen-López, J.M.; Mansfeld, F. Evaluation of different sealing methods for anodized aluminum-silicon carbide ( $\mathrm{Al} / \mathrm{SiC}$ ) composites using EIS and SEM techniques. Mater. Corros. 2007, 58, 825-832. [CrossRef]

38. Ma, T.; Wua, H.; Zhoub, X.; Lic, K.; Liaod, Y.; Lianga, Z.; Liua, L. Corrosion behavior of anodized Al-Cu-Li alloy: The role of intermetallic particle-introduced film defects. Corros. Sci. 2019, 58, 108110. [CrossRef]

39. Wu, H.; Ma, Y.; Huang, W.; Zhou, X.; Li, K.; Liao, Y.; Wang, Z.; Liang, Z.; Liu, L. Effect of iron-containing intermetallic particles on film structure and corrosion resistance of anodized AA2099 alloy. J. Electrochem. Soc. 2018, 165, C573-C581. [CrossRef]

40. Schneider, M.; Kremmer, K. Corrosion behavior of anodized AA-6060 depending on the anodizing bath aging. Mater. Corros. 2019, 70, 2041-2051. [CrossRef]

41. Gao, Z.; Cao, J.; Chen, Y.; Muzammal, H.M.; Wang, W. Effect of Cu preferential orientation on the microstructure and property of anodized CuxO film. Eur. J. Inorg. Chem. 2020, 2020, 261-268. [CrossRef]

42. Zeng, D.; Liu, Z.; Bai, S.; Wang, J. Influence of sealing treatment on the corrosion resistance of PEO coated Al-Zn-Mg-Cu alloy in various environments. Coatings 2019, 9, 867. [CrossRef] 
43. Hua, L.; Liu, J.; Li, S.; Yu, M. Effect of adipic acid on deis characteristics during the aluminium anodizing process in sulfuric acid bath. Int. J. Electrochem. Sci. 2015, 10, 2194-2205.

44. Brett, C.M.A. The application of electrochemical impedance techniques to aluminium corrosion in acidic chloride Solution. J. App. Electrochem. 1990, 20, 1000-1003. [CrossRef]

45. Bastidas, D.M. Interpretation of impedance data for porous electrodes and diffusion processes. Corrosion 2007, 63, 515-521. [CrossRef]

46. Jirón-Lazos, U.; Corvo, F.; De la Rosa-García, S.; García-Ochoa, E.; Bastidas, D. Localized corrosion of aluminum alloy 6061 in the presence of Asper gillus niger. Int. Biodeter. Boidegr. 2018, 133, 17-25. [CrossRef]

47. Jinlong, L.; Tongxiang, L.; Chen, W.; Ting, G. The passive film characteristics of several plastic deformation 2099 Al-Li alloy. J. Alloys Compd. 2016, 662, 143-149. [CrossRef]

48. Pivac, I.; Barbir, F. Inductive phenomena at low frequencies in impedance spectra of proton exchange membrane fuel cells-A review. J. Power Sources 2016, 326, 112-119. [CrossRef]

49. Alexe-Ionescu, A.L.; Barbero, G.; Evangelista, L.R.; Lenzi, E.K. Current-voltage characteristics and impedance spectroscopy: Surface conduction and adsorption-desorption effects in electrolytic cells. J. Phys. Chem. C 2020, 124, 3150-3158. [CrossRef]

50. Djellab, M.; Bentrah, H.; Chala, A.; Taoui, H. Synergistic effect of halide ions and gum arabic for the corrosion inhibition of API5L X70 pipeline steel in $\mathrm{H}_{2} \mathrm{SO}_{4}$. Mater. Corros. 2019, 70, 149-160. [CrossRef]

51. Bastidas, J.M.; Polo, J.; Torres, C.; Cano, E. A study on the stability of AISI 316L stainless steel pitting corrosion through its transfer function. Corros. Sci. 2001, 43, 269-281. [CrossRef]

52. Klotz, D. Negative capacitance or inductive loop?-A general assessment of a common low frequency impedance feature. Electrochem. Commun. 2019, 98, 58-62. [CrossRef]

53. Usman, B.J.; Scenini, F.; Curioni, M. Corrosion testing of anodized aerospace alloys: Comparison between immersion and salt spray testing using electrochemical impedance spectroscopy. J. Electrochem. Soc. 2020, 167, 041505. [CrossRef]

54. Huang, Y.; Shih, H.; Huang, H.; Daugherty, J.; Wu, S.; Ramanathan, S.; Chang, C.; Mansfeld, F. Evaluation of the corrosion resistance of anodized aluminum 6061 using electrochemical impedance spectroscopy (EIS). Corros. Sci. 2008, 50, 3569-3575. [CrossRef]

55. Zapata-Loría, A.D.; Pech-Canul, M.A. Corrosion inhibition of aluminum in $0.1 \mathrm{M}$ HCL solution by glutamic acid. Chem. Eng. Commun. 2014, 201, 855-869. [CrossRef]

56. Suay, J.; Giménez, E.; Rodriguez, T.; Habbib, K.; Saura, J. Characterization of anodized and sealed aluminium by EIS. Corros. Sci. 2003, 45, 611-624. [CrossRef]

57. Wang, S.; Peng, H.; Shao, Z.; Zhao, Q.; Du, N. Sealing of anodized aluminum with phytic acid solution. Surf. Coat. Technol. 2015, 286, 155-164. [CrossRef]

58. Saeedikhani, M.; Javidi, M.; Yazdani, A. Anodizing of 2024-T3 aluminum alloy in sulfuric-boric-phosphoric acids and its corrosion behavior. Trans. Nonferrous Met. Soc. China 2013, 23, 2551-2559. [CrossRef]

59. Hsu, C.H.; Mansfeld, F. Technical note: Concerning the conversion of the constant phase element parameter $Y 0$ into a capacitance. Corrosion 2001, 57, 747-748. [CrossRef]

60. Scully, J.R.; Silverman, D.C.; Kendig, M.W. Electrochemical Impedance: Analysis and Interpretation STP 1188; ASTM International: Philadelphia, PA, USA, 1993. [CrossRef]

61. Pérez, N. Electrochemistry and Corrosion Science; Springer: New York, NY, USA, 2004.

62. Hirschorn, B.; Orazem, M.E.; Tribollet, B.; Vivier, V.; Frateur, I.; Musiani, M. Determination of effective capacitance and film thickness from constant-phase-element parameters. Electrochim. Acta 2010, 55, 6218-6227. [CrossRef]

63. Evertsson, J.; Bertram, F.; Rullik, L.; Harlow, G.; Lundgren, E. Anodization of Al (100), Al (111) and Al Alloy 6063 studied in situ with X-ray reflectivity and electrochemical impedance spectroscopy. J. Electroanal. Chem. 2017, 799, 556-562. [CrossRef]

64. Cabral-Miramontes, J.A.; Barceinas-Sánchez, J.D.O.; Poblano-Salas, C.A.; Pedraza-Basulto, G.K.; Nieves-Mendoza, D.; ZambranoRobledo, P.C.; Almeraya-Calderón, F.; Chacón-Nava, J.G. Corrosion behavior of AISI 409Nb stainless steel manufactured by powder metallurgy exposed in $\mathrm{H}_{2} \mathrm{SO}_{4}$ and $\mathrm{NaCl}$ solutions. Int. J. Electrochem. Sci. 2013, 8, 564-577.

65. Ayagou, M.D.D.; Tran, T.T.M.; Tribollet, B.; Kittel, J.; Sutter, E.; Ferrando, N.; Mendibide, C.; Duret-Thual, C. Electrochemical impedance spectroscopy of iron corrosion in $\mathrm{H}_{2} \mathrm{~S}$ solutions. Electrochim. Acta 2018, 282, 775-783. [CrossRef]

66. Núñez-Jaquez, R.E.; Buelna-Rodríguez, J.E.; Barrios-Durstewitz, C.P.; Gaona-Tiburcio, C.; Almeraya-Calderón, F. Corrosion of modified concrete with sugar cane bagasse ash. Int. J. Corros. 2012, 2012, 1-5. [CrossRef]

67. Zhao, X.-H.; Zuo, Y.; Zhao, J.-M.; Xiong, J.-P.; Tang, Y.-M. A study on the self-sealing process of anodic films on aluminum by EIS. Surf. Coat. Technol. 2006, 200, 6846-6853. [CrossRef]

68. Khadiri, M.; Elyaagoubi, M.; Idouhli, R.; Koumya, Y.; Zakir, O.; Benzakour, J.; Benyaich, A.; Abouelfida, A.; Outzourhit, A. Electrochemical study of anodized titanium in phosphoric acid. Adv. Mater. Sci. Eng. 2020, 2020, 1-11. [CrossRef]

69. Ono, S.; Asoh, H. Mechanism of hot water sealing of anodic films formed on aluminum. Corros. Sci. 2021, 181, 109221. [CrossRef]

70. Martinez-Villafañe, A.; Chacon-Nava, J.; Gaona-Tiburcio, C.; Almeraya-Calderon, F.; Domínguez-Patiño, G.; Gonzalez-Rodríguez, J. Oxidation performance of a Fe-13Cr alloy with additions of rare earth elements. Mater. Sci. Eng. A 2003, 363, 15-19. [CrossRef]

71. Boukamp, B.A. Interpretation of an 'inductive loop' in the impedance of an oxygen ion conducting electrolyte/metal electrode system. Solid State Ion. 2001, 143, 47-55. [CrossRef] 
72. Corral, H.R.; Arredondo, R.S.P.; Neri, F.M.; Gómez, S.J.M.; Almeraya, C.F.; Castorena, G.J.H.; Almaral, S.J. Sulfate attack and reinforcement corrosion in concrete with recycled concrete aggregates and supplementary cementing materials. Int. J. Electrochem. Sci. 2011, 6, 613-621.

73. Ofoegbu, S.U.; Fernandes, F.A.; Pereira, A.B. The sealing step in aluminum anodizing: A focus on sustainable strategies for enhancing both energy effciency and corrosion resistance. Coatings 2020, 10, 226. [CrossRef]

74. Miramontes, J.A.C.; Sánchez, J.D.O.B.; Calderón, F.A.; Villafañe, A.M.; Nava, J.G.C. Effect of boron additions on sintering and densification of a ferritic stainless steel. J. Mater. Eng. Perform. 2010, 19, 880-884. [CrossRef]

75. Macdonald, D.D.; Sikora, E.; Engelhardt, G. Characterizing electrochemical systems in the frequency domain. Electrochim. Acta 1998, 43, 87-107. [CrossRef]

76. Cao, C.-N. On the impedance plane displays for irreversible electrode reactions based on the stability conditions of the steadystate-II. Two state variables besides electrode potential. Electrochim. Acta 1990, 35, 837-844. [CrossRef]

77. Clerc, C.; Landolt, D. AC impedance study of anodic films on nickel in LiCl. Electrochim. Acta 1988, 33, 859-871. [CrossRef]

78. Elkin, V.V.; Marshakov, A.I.; Rybkina, A.A.; Maleeva, M. Interpretation of the impedance comprising negative capacitance and constant phase elements on iron electrode in weakly acidic media. Russ. J. Electrochem. 2011, 47, 136-146. [CrossRef]

79. Strohmeier, B.R. An ESCA method for determining the oxide thickness on aluminum alloys. Surf. Interface Anal. 1990, 15, 51-56. [CrossRef]

80. Pérez, O.E.L.; Sánchez, M.D.; Teijelo, M.L. Characterization of growth of anodic antimony oxide films by ellipsometry and XPS. J. Electroanal. Chem. 2010, 645, 143-148. [CrossRef]

81. Alexander, M.R.; Thompson, G.E.; Beamson, G. Characterization of the oxide/hydroxide surface of aluminium using X-ray photoelectron spectroscopy: A procedure for curve fitting the O 1s core level. Surf. Interface Anal. 2000, 29, 468-477. [CrossRef]

82. Feliu, S.; Bartolomé, M.J.; González, J.A.; Feliu, S. XPS characterization of porous and sealed anodic films on aluminum alloys. J. Electrochem. Soc. 2007, 154, C241-C248. [CrossRef]

83. Caicedo-Martinez, C.E.; Koroleva, E.; Skeldon, P.; Thompson, G.E.; Hoellrigl, G.; Bailey, P.; Noakes, T.C.Q.; Habazaki, H.; Shimizu, K. Behavior of impurity and minor alloying elements during surface treatments of aluminum. J. Electrochem. Soc. 2002, 149, B139-B145. [CrossRef]

84. Paez, A.M.; Bustos, O.; Thompson, E.G.; Skeldon, P.; Shimizu, K.; Wood, C.G. Porous anodic film formation on an Al-3.5 wt.\% Cu Alloy. J. Electrochem. Soc. 2000, 147, 1015. [CrossRef]

85. Romios, M.; Tiraschi, R.; Parrish, C.; Babel, H.W.; Ogren, J.R.; Es-Said, O.S. Design of multistep aging treatments of 2099 (C458) Al-Li Alloy. J. Mater. Eng. Perform. 2005, 14, 641-646. [CrossRef]

86. Abrahami, S.; Hauffman, T.; De Kok, J.M.; Mol, A.; Terryn, H. XPS analysis of the surface chemistry and interfacial bonding of barrier-type Cr (VI)-free anodic oxides. J. Phys. Chem. C. 2015, 119, 19967-19975. [CrossRef]

87. Skeldon, P.; Wang, H.; Thompson, G. Formation and characterization of self-lubricating $\mathrm{MoS}_{2}$ precursor films on anodized aluminium. Wear 1997, 206, 187-196. [CrossRef]

88. Khan, M.F.; Kumar, A.M.; Ul-Hamid, A.; Al-Hems, L.M. Achieving non-adsorptive anodized film on Al-2024 alloy: Surface and electrochemical corrosion investigation. Surf. Interfaces 2019, 15, 78-88. [CrossRef]

89. Ryu, S.-K.; Park, B.-J.; Park, S.-J. XPS analysis of carbon fiber surfaces-Anodized and interfacial effects in fiber-epoxy composites. J. Colloid Interface Sci. 1999, 215, 167-169. [CrossRef]

90. Duong, L.V.; Wood, B.J.; Kloprogge, J.T. XPS study of basic aluminum sulphate and basic aluminium nitrate. Mater. Lett. 2005, 59, 1932-1936. [CrossRef]

91. Zähr, J.; Oswald, S.; Türpe, M.; Ullrich, H.; Füssel, U. Characterisation of oxide and hydroxide layers on technical aluminum materials using XPS. Vacuum 2012, 86, 1216-1219. [CrossRef]

92. Martínez-Villafañe, A.; Almeraya-Calderón, M.; Gaona-Tiburcio, C.; Gonzalez-Rodriguez, J.; Porcayo-Calderon, J. Hightemperature degradation and protection of ferritic and austenitic steels in steam generators. J. Mater. Eng. Perform. 1998, 7, 108-113. [CrossRef]

93. Zhang, Z.; Zhang, Y.; Guo, Y.; Chen, X.; Chen, L. Impurity element analysis of aluminum hydride using PIXE, XPS and elemental analyzer technique. Nucl. Instrum. Methods. Phys. Res. B Beam Interact. Mater. At. 2021, 488, 1-4. [CrossRef]

94. Ramirez-Arteaga, A.M.; Gonzalez-Rodriguez, J.G.; Campillo, B.; Gaona-Tiburcio, C.; Dominguez-Patiño, G.; Leduc Lezama, L.; Chacon-Nava, J.G.; Neri-Flores, M.A.; Martinez-Villafañe, A. An electrochemical study of the corrosion behavior of a dual phase steel in $0.5 \mathrm{~m} \mathrm{H}_{2} \mathrm{SO}_{4}$. Int. J. Electrochem. Sci. 2010, 5, 1786-1798.

95. Vac, J. Practical guide for curve fitting in X-ray photoelectron spectroscopy. Sci. Technol. 2020, 38, 061203. [CrossRef]

96. Sherwood, P.M.A. Introduction to studies of aluminum and its compounds by XPS. Surf. Sci. Spectra 1998, 5, 1-3. [CrossRef]

97. Paparazzo, E. XPS and auger spectroscopy studies on mixtures of the oxides $\mathrm{SiO}_{2}, \mathrm{Al}_{2} \mathrm{O}_{3}, \mathrm{Fe}_{2} \mathrm{O}_{3}$ and $\mathrm{Cr}_{2} \mathrm{O}_{3}$. J. Electron Spectrosc. Relat. Phenom. 1987, 43, 97-112. [CrossRef] 